\title{
Effects of zinc on the life-cycle, growth and reproduction of the marine amphipod Corophium volutator
}

\author{
Mercedes Conradi*, Michael H. Depledge \\ Plymouth Environmental Research Centre, University of Plymouth, Ecotoxicology Laboratory, Drake Circus, \\ Plymouth PL4 8AA, United Kingdom
}

\begin{abstract}
The effects of zinc concentrations on the life-history, growth and reproduction of Corophium volutator (Pallas, 1766) were investigated. Amphipods were exposed for $100 \mathrm{~d}$ to $4 \mathrm{sub}-$ lethal zinc concentrations $\left(0.2,0.4,0.6\right.$ and $\left.0.8 \mathrm{mg} \mathrm{l}^{-1}\right)$. Except for the highest concentration tested, zinc exposure did not affect the life-span of $C$. volutator, although the number of surviving amphipods decreased with increasing concentrations. Life expectancy at the end of the experiment differed at the various zinc exposure concentrations $(\mathrm{p}<0.001)$. Zinc concentrations higher than $0.6 \mathrm{mg} \mathrm{l}^{-1}$ reduced longevity up to $20 \%$ in comparison with controls. Growth was also impaired. The degree of reduction

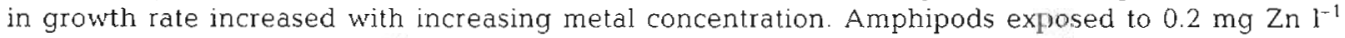
exhibited a reduction of $6.4 \%$ in the specific growth rate (SGR), while those grown at $0.4,0.6$, and

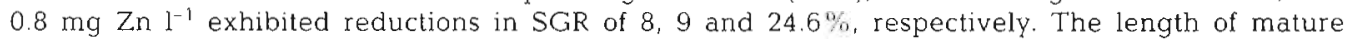
amphipods was also reduced following zinc exposure $(p<0.05)$. Sex ratio was unaffected $(p=0.44)$, however maturation rates were slightly reduced and fertility was greatly impaired. Survival of ovigerous females and fertility were also affected by zinc when mature amphipods were exposed to these concentrations. The relationship between growth and reproduction as well as the use of growth as an endpoint in ecotoxicological studies is discussed.
\end{abstract}

KEY WORDS: Population · Corophium volutator $\cdot$ Zinc $\cdot$ Life-history $\cdot$ Growth $\cdot$ Reproduction

\section{INTRODUCTION}

Ecotoxicology differs from classical toxicology in that, rather than being concerned with the study of toxic effects on individual organisms, it addresses the impact of pollutants on populations, communities and ecosystems (Truhaut 1977). The current approach used in aquatic ecotoxicology for investigating population level effects involves the use of life-tables and demographic studies. In this method, the age-specific mortality and fecundity of individuals are recorded throughout the life span of a cohort and used to estimate effects on populations. Life-table studies with

\footnotetext{
- Address for correspondence: Departamento de Biologia Animal, Vegetal y Ecologia, Fac. Ciencias Experimentales, Universidad de Jaén, Paraje Las Lagunillas $s / n$, Edificio no. 5 , E-23071 Jaén, Spain.E-mail: mconradi@vjaen.es
}

invertebrates have been mostly confined to relatively short-lived organisms (e.g. Kirk 1992, Enserink et al. 1995, Calbet \& Alcaraz 1997, Lotufo \& Fleeger 1997), and only a few with long-lived macroinvertebrates with complex life histories, such as the amphipod Gammarus pulex (Maund et al. 1992) have been studied in this manner.

The tube-dwelling amphipod Corophium volutator (Pallas, 1766) has many of the characteristics necessary for life-cycle studies in the laboratory. For example, it is widely distributed and available in large numbers, and it facultatively feeds on sediment and suspended particulate matter, has a wide tolerance range for salinity and can be cultured in captivity. This amphipod has been used in a variety of ecotoxicological investigations (i.e. V. Bryan et al. 1984, 1985a, b, Van der Hurk et al. 1992, Eriksson \& Weeks 1994, Roddie et al. 1994, Ciarelli et al. 1997), but nearly all of these 
studies have been undertaken mainly to determine $\mathrm{LCC}_{30}$, and short-term toxicity tests using amphipods have generally lasted for 2 or $3 \mathrm{~d}$, although some have lasted as long as $10 \mathrm{~d}$ and a few as long as $28 \mathrm{~d}$. These tests do not take into account feeding of the amphipods, which does not take place in such a short time, sensitivity of juveniles, or the influence of temperature not only on sensitivity of the animals but also on growth and/or reproduction.

In British waters the most obvious metallic contamination occurs in estuaries, where incoming trace metals of natural and anthropogenic origin tend to become trapped. Most zinc-contaminated areas are associated with sewage sludge dumping or ancillary industries such as the china clay industry. Elevated zinc levels can also be due to natural causes, which are exacerbated by historic mining activities. Zinc concentrations in sewage sludge in the form dumped at sea in the UK range from 93 to $1660 \mu \mathrm{g} \mathrm{g}^{-1}$ off Plymouth (Halcrow et al. 1973) to $3980 \mu \mathrm{g} \mathrm{g} \mathrm{g}^{-1}$ in the outer Thames Estuary (Norton et al. 1981). In sediments receiving sewage sludge, the concentrations of zinc are known to reach up to $1200 \mu \mathrm{g} \mathrm{g}^{-1}$, e.g. in Liverpool Bay (MAFF, Directorate of Fisheries Research, 1992). Zinc sediment concentrations in Restronguet Creek, Cornwall, reach $3500 \mathrm{\mu g} \mathrm{g}^{-1}$ (G. H. Bryan et al. 1985), but as a result of mining effluent rather than sludge dumping.

Recently, the interactions among Corophium volutator, zinc and sediment have been studied by Bat et al. (1998) while studies on the uptake, accumulation and excretion of this trace metal by this amphipod are currently underway (P. S. Rainbow pers. comm.). While it is important to evaluate the acute toxicity of a pollutant, from an ecological point of view there is also a need to determine long term sublethal responses, which could threaten the survival, growth or reproduction of a species, and, in some instances, affect the equilibrium of the ecosystem (Moriarty 1983).

In the present study the mode of action of zinc in neither the sediment nor the tissues is addressed. Instead, attention is focussed on the effects of sublethal zinc concentrations on demographic parameters for the estuarine amphipod Corophium volutator.

\section{MATERIALS AND METHODS}

Collection and maintenance of amphipods. Stocks of Corophium volutator were collected by sieving mud through a $1 \mathrm{~mm}$ mesh in the intertidal zone of the Tamar Estuary (UK) on 15 April 1996. Sediment was collected from the field (upper $5 \mathrm{~mm}$ ) and sieved to remove associated macrofauna and large debris $10.5 \mathrm{~mm}$ mesh size). This fine sieve facilitated the recovery of new juveniles. A total of 150 amphipods (male:female sex ratio $=0.65$, no ovigerous females) were maintained in a $25 \mathrm{l}$ glass tank with $7 \mathrm{~mm}$ of homogenised sediment, which was equally distributed through the aquarium, and $8 \mathrm{l}$ of continuously aerated, filtered, $25 \%$ seawater Remaining amphipods were preserved in $70 \%$ ethanol with glycerine. Temperature was maintained at $15 \pm 1^{\circ} \mathrm{C}$ and a light regime of $12 \mathrm{~h}$ light: $12 \mathrm{~h}$ dark was employed. Twice per week the water was changed and the amphipods were fed with 'Liquifry Marine' (Interpret Ltd, Prod 0308, Label 03030). At least once per week the sediment was sieved $(0.5 \mathrm{~mm}$ mesh size), the animals counted and their development observed. Recently liberated juveniles were obtained by sieving the sediment on 23-24 May 1996.

Growth experiment. Groups of 50 seven-day-old juveniles (average size $=1.4 \pm 0.4 \mathrm{~mm}$ ) were maintained in acid-washed $1 \mathrm{l}$ glass tanks containing $0.5 \mathrm{l}$ of continuously aerated, filtered water overlaying 3 to $4 \mathrm{~mm}$ of sediment (sieved though $0.5 \mathrm{~mm}$ mesh size). Amphipods were exposed to different concentrations of zinc: $<0.001$ (control), $0.2,0.4,0.6$, and $0.8 \mathrm{mg} \mathrm{I}^{-1}$ (zinc chloride). Two replicate series of each treatment were carried out simultaneously. The conditions for the cultures were the same as for the stock population, with the temperature and salinity kept constant throughout the experiment since they can affect the toxicity of some trace metals (i.e. V Bryan et al. 1984, $1985 \mathrm{a}$, b). Twice per week, the amphipods were counted and sexed, and dead amphipods or cast exuviae were removed. At least once a week animals were measured to the nearest $0.05 \mathrm{~mm}$. Individuals were sexed and measured as in Conradi \& Depledge (1998).

Reproduction experiment. The experiment was initiated with mature animals from the stock population (average size $=5$ to $7 \mathrm{~mm}$ ) but no ovigerous females were chosen. Conditions of the cultures and zinc concentrations were the same as in the growth experiment. Eight females and 4 males were used in each tank. Two replicate series of each treatment were carried out simultaneously. Twice per week, the developmental stage of the females was examined. Maturity was defined as the number of ovigerous females in the population and fertility as the number of the offspring of the population per surviving female.

Data analyses. Survivorship $\left(l_{x}\right)$, mortality rate $\left(q_{x}\right)$ and life expectancy $\left(e_{\mathrm{x}}\right)$ were computed for all replicates using standard life-table methods (Krebs 1978, Daniels \& Allan 1981). All results are averages of the 2 replicates. One-way ANOVA was used to compare these indices at different concentrations of zinc after checking homogeneity of variances with Barlett's test.

Statistical comparisons among populations were performed using a nonparametric test, Kruskal-Wallis 1 -way analysis of variance by ranks. Differences among growth rates were calculated using multiple 
regression analysis. The data were transformed $\left(\mathrm{X}^{1 / 3}\right)$ to homogenise the variances. As the number of surviving animals decreased as the toxic effect increased, the regressions were weighted with $n^{1 / 2}$, where $n$ is the number of surviving animals.

Specific growth rate (SGR) was considered as a rate of increase in length related to the length of the animal. The mean specific growth rate of each treatment per day was expressed as a percentage of that of the control: the $\mathrm{E}: \mathrm{C}$ ratio (i.e. Manley et al. 1984, Redpath 1985), where $\mathrm{E}: \mathrm{C}=\ln L_{\text {expt }} \times 100 / \ln L_{\text {control }}(L=$ length of the animals). The assumption is therefore that the normal growth rate of the experimental animal is that of the control and that any variations in environmental conditions will affect the rate of the growth of control and experimental animals equally.

\section{RESULTS}

\section{Survival}

Except in the highest concentration tested, zinc stress did not significantly affect the life span of Corophium volutator, although its toxicity is reflected in the survivorship curves (Fig. 1). The life span of control populations and those grown at concentrations lower than $0.6 \mathrm{mg} \mathrm{Zn}^{-1}$ was higher than $100 \mathrm{~d}_{\text {; however, }}$ animals grown at $0.8 \mathrm{mg} \mathrm{Zn}^{-1}$ did not survive up to $90 \mathrm{~d}$. Furthermore, the number of surviving animals was reduced by this trace metal $(p=0.01)$. Populations

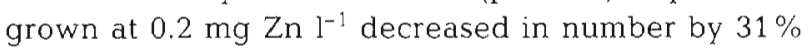
with respect to the control, and those exposed to 0.4

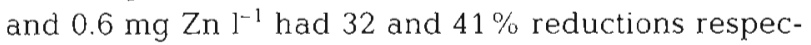

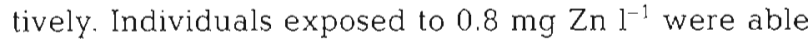
to survive up to $70 \mathrm{~d}$.

Controls exhibited the highest mortality rate on $3 \mathrm{~d}$ of culturing $\left(q_{x}=0.08\right)$. Subsequently, the rate was low and almost constant during the experiment. Populations exposed to zinc concentrations below $0.6 \mathrm{mg} \mathrm{l}^{-1}$ showed a high juvenile mortality, while those grown at $0.8 \mathrm{mg} \mathrm{Zn}^{-1}$ had an almost constant mortality rate.

Longevity, expressed as the day at which $50 \%$ of the original population survived, was reduced by zinc. Longevity for Corophium volutator in the control was higher than the $100 \mathrm{~d}$ of culturing. Individuals exposed to $0.2,0.4$ and $0.6 \mathrm{mg} \mathrm{Zn}^{-1}$ showed a decrease in their longevity to $81.5,88.5$ and $70 \mathrm{~d}$ respectively. Populations grown at $0.8 \mathrm{mg} \mathrm{Zn} 1^{-1}$ had their longevity reduced to $53.5 \mathrm{~d}$.

Life expectancy $\left(e_{\mathrm{x}}\right)$ was greater after 1 wk of culturing than at the beginning of the experiment due to the

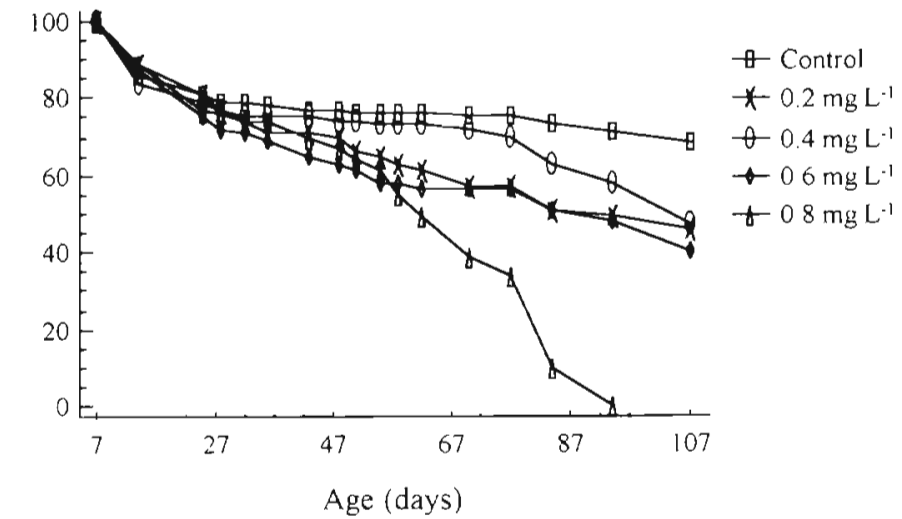

g. 1. Corophium volutator. Age-specific survivorship $\left(l_{x}\right)$ of amphipods at different zinc concentrations

acclimation of the amphipods to the new environmental conditions. Zinc impaired the life expectancy of Corophium volutator at the end of the experiment

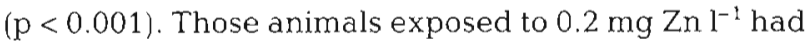
their life expectancy reduced to $0.82 \%$ with respect to the controls. Two populations, those grown at 0.4 and $0.6 \mathrm{mg} \mathrm{Zn} \mathrm{l}^{-1}$, showed a reduction of $7.8 \%$, while pop-

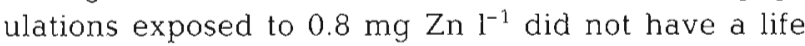
expectancy higher than $77 \mathrm{~d}$.

\section{Growth}

Fig. 2 shows multiple box-and-whisker plots for the length of Corophium volutator in populations at various zinc concentrations. Growth rate decreased with increasing zinc concentration. Amphipods in the control population (Fig. 2A) reached a maximum length of $8 \mathrm{~mm}$ (5.7 times their initial length) while amphipods exposed to $0.2 \mathrm{mg} \mathrm{Zn}^{-1}$ had a maximal length of $7.2 \mathrm{~mm}$ (Fig. 2B). Zinc concentrations of 0.4 and $0.6 \mathrm{mg}$ $\mathrm{Zn} \mathrm{l}^{-1}$ reduced the maximum length of $C$. volutator to $6.8 \mathrm{~mm}$ and $6.4 \mathrm{~mm}$ respectively $(4.8$ and 4.6 times their initial length) (Fig. 2C, D, respectively). More than 25 and $70 \%$ of individuals in the populations exposed to 0.4 and $0.6 \mathrm{mg} \mathrm{Zn} \mathrm{l}^{-1}$ were smaller than $4.8 \mathrm{~mm}$ at the end of the experiment (age $107 \mathrm{~d}$ ). Amphipods in the population grown at $0.8 \mathrm{mg} \mathrm{Zn}^{-1}$ exhibited a 3 -fold increase in body length (maximum length $=4.4 \mathrm{~mm}$ ) (Fig. $2 \mathrm{E}$ )

Body lengths in populations exposed to different zinc concentrations were significantly different from those in controls on all days examined ( $p<0.0001)$.

Zinc provoked a reduction in the specific growth rate (SGR) at all concentrations studied. The degree of reduction in growth rate increased with increasing metal concentration. At age $84 \mathrm{~d}$, amphipods exposed 

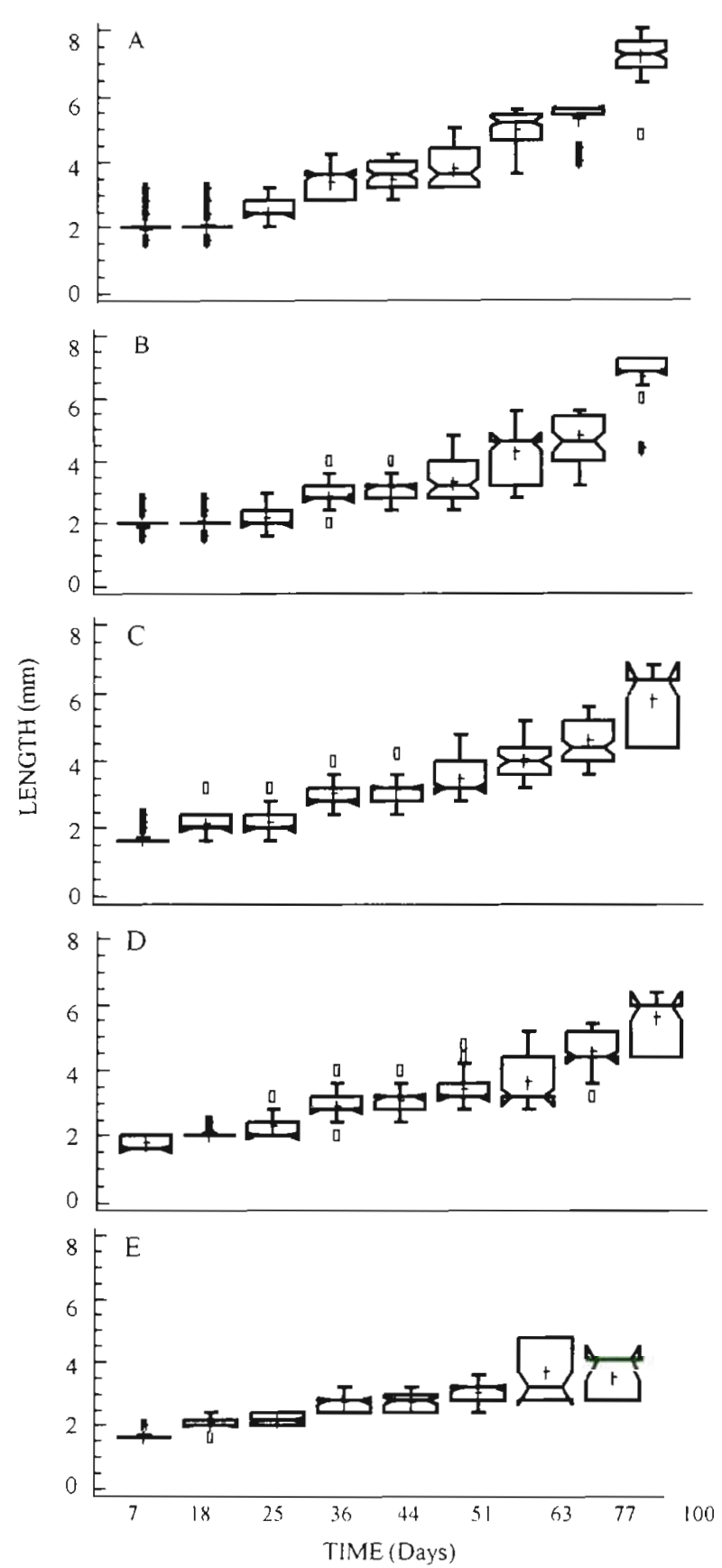

Fig. 2. Corophium volutator. Multiple Box-and-whisker plots of amphipod length for populations exposed to (A) $<0.001$ (control), (B) 0.2, (C) 0.4, (D) 0.6 and (E) $0.8 \mathrm{mg} \mathrm{Zn}^{-1}$

to $0.2 \mathrm{mg} \mathrm{Zn}^{-1}$ showed a $6.4 \%$ reduction in $\mathrm{SGR}$,

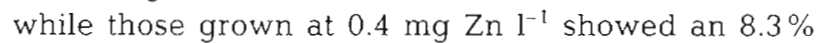

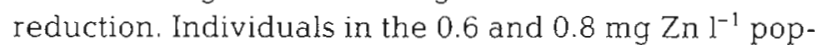
ulations showed 9 and $24.6 \%$ reductions in $S G R$ respectively.

As the lengths of individuals in the initial populations grown at different zinc concentrations were not significantly different, the multiple analysis regression showed no significant difference among the intercepts of the fitted regressions ( $\mathrm{p}=0.886$ ). In contrast, all the slopes of the regressions were significantly different from the control (Table 1).

\section{Reproduction}

The minimum period necessary for sexual differentiation was estimated to be $44 \mathrm{~d}$ for the control and 0.2 and $0.4 \mathrm{mg} \mathrm{Zn} \mathrm{I}^{-1}$ populations. Seven days later (Day 51), the first animal at $0.6 \mathrm{mg} \mathrm{Zn} \mathrm{I}^{-1}$ exhibited sexual differentiation. This time the differentiation increased up to $8 \mathrm{~d}$ for populations grown at $0.8 \mathrm{mg} \mathrm{Zn}$ $\mathrm{l}^{-1}$. In addition, based on the observation of the first ovigerous female, the minimum period for female sexual maturation was estimated at $58 \mathrm{~d}$ from birth in control and 0.2 and $0.4 \mathrm{mg} \mathrm{Zn} \mathrm{l^{-1 }}$ populations, and $77 \mathrm{~d}$

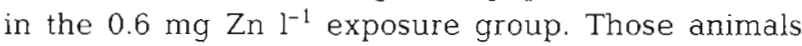
growth at $0.8 \mathrm{mg} \mathrm{Zn}^{-1}$ were not able to reach sexual maturation.

The length of mature animals was significantly affected by zinc ( $p=0.000$ for both sexes). The average length of both males and ovigerous females varied with zinc exposure from $7 \mathrm{~mm}$ in the control to $6.1 \mathrm{~mm}$ in the $0.6 \mathrm{mg} \mathrm{I}^{-1}$ treatment (Table 2).

Fig. 3 shows the stages of sexual differentiation in Corophium populations at different zinc concentrations. Sexual differentiation was affected by zinc $(p<$ $0.05)$; thus, the higher the concentration of this trace metal, the smaller the percentage of adults in the population. After $77 \mathrm{~d}$ of culturing, $97.3 \%$ of the control animals were adults; this percentage was slightly lower, $86.3 \%$, at $0.2 \mathrm{mg} \mathrm{Zn} \mathrm{l^{-1 }}$ and was reduced to 73 and $70.6 \%$ at 0.4 and $0.6 \mathrm{mg} \mathrm{Zn} \mathrm{l}^{-1}$ respectively. Only

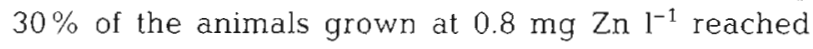
maturity by $77 \mathrm{~d}$.

Sex ratio (males:females) was not significantly affected by zinc exposure $(p=0.44)$ : the overall sex ratio in the control was 1 ; in those populations grown at 0.2 and $0.4 \mathrm{mg} \mathrm{Zn}^{-1}$ it was 1.2 , and in the $0.6 \mathrm{mg} \mathrm{Zn}^{-1}$ populations it was 0.9 .

Maturation of Corophium volutator number of ovigerous female in the population) was strongly reduced by zinc ( $p=0.0043$ ) (Fig, 4). Maturation was maximal after $77 \mathrm{~d}$ of culturing at all concentrations investigated, but the populations grown at 0.2 and $0.4 \mathrm{mg} \mathrm{Zn} \mathrm{l^{-1 }}$ presented a reduction of $61.5 \%$ in the number of ovigerous females with respect to the con-

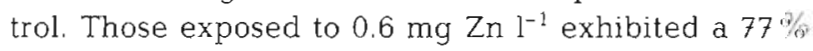

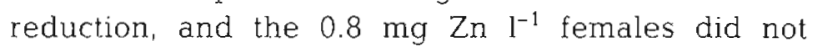
become ovigerous. Fertility was also strongly affected by zinc. While controls had a fertility of 20 offspring per female, the maximum number of juveniles ob- 
Table 1. Corophium volutator. Values of the slopes of the fitted regression models for the average lengths of amphipods exposed to different zinc concentrations. $R^{2}=98.25 \%$; ns: no significant difference; $\cdot p<0.01 ; \cdots p<0.005$

\begin{tabular}{|lcc|}
\hline Zinc conc. $\left(\mathrm{mg} \mathrm{l}^{-1}\right)$ & Slope & Intercept \\
\hline$<0.001$ (control) & 0.0081 & 1.15 \\
0.2 & $0.0072^{\circ}$ & $\mathrm{ns}$ \\
0.4 & $0.0068^{\circ}$ & $\mathrm{ns}$ \\
0.6 & $0.0066^{*}$ & $\mathrm{~ns}$ \\
0.8 & $0.0062^{\circ}$ & $\mathrm{ns}$ \\
\hline
\end{tabular}

Table 2. Corophium volutator. Effect of zinc on the average (avg.), maximum (max.) and minimum (min.) length of adult amphipods

\begin{tabular}{|lcccccc}
\hline \multirow{2}{*}{$\begin{array}{l}\text { Zinc conc. } \\
\text { (mg l-1) }\end{array}$} & \multicolumn{3}{c}{ Male (mm) } & \multicolumn{3}{c}{ Female (mm) } \\
& Max. & Min. & Avg. & Max & Min. & Avg. \\
\hline 0.001 (control) & 8.0 & 5.0 & 7.0 & 8.0 & 4.8 & 7.2 \\
0.2 & 7.2 & 4.8 & 6.8 & 8.0 & 4.6 & 7.0 \\
0.4 & 6.8 & 4.8 & 6.2 & 5.4 & 4.6 & 5.3 \\
0.6 & 6.4 & 4.8 & 6.1 & 4.4 & 4.0 & 4.2 \\
0.8 & - & - & - & - & - & - \\
& & & & & & \\
\hline
\end{tabular}

tained from populations exposed to zinc was $6(0.2 \mathrm{mg}$ $\mathrm{Zn}^{-1}$ populations).

Mature Corophium volutator were exposed for $45 \mathrm{~d}$ to the same zinc concentrations. In this case, the total number of surviving amphipods was not affected $(\mathrm{p}=$ 0.09), although the survivorship of the females was reduced $(p<0.01)$, Fig. $5 B$ ). Zinc exposure impaired neither mating nor maturation; however, it significantly reduced the fertility of mature animals ( $\mathrm{p}<$ 0.001 , Fig. 5A). The number of offspring per female decreased with increasing zinc concentrations. Even the lowest concentration tested, $0.2 \mathrm{mg} \mathrm{Zn} \mathrm{I}^{-1}$, had a high impairment on the number of new individuals per female. Zinc not only decreased fertility but also the survivorship of the juveniles, at least at the highest concentration, $0.8 \mathrm{mg} \mathrm{Zn}^{-1}$, investigated (Fig. 5C).

\section{DISCUSSION}

The acute toxicity of $\mathrm{Zn}$ for Corophium volutator has been calculated to be $14.12 \mathrm{mg} \mathrm{l}^{-1}$ (Bat et al. 1998); however, sublethal long-term zinc exposure (concentrations 70 times lower than the $\mathrm{LC}_{50}$ ) reduced the survivorship and life expectancy of this amphipod. Except for the highest concentration tested, juveniles were more sensitive to this metal than mature animals, which is consistent with the findings of previous stud-

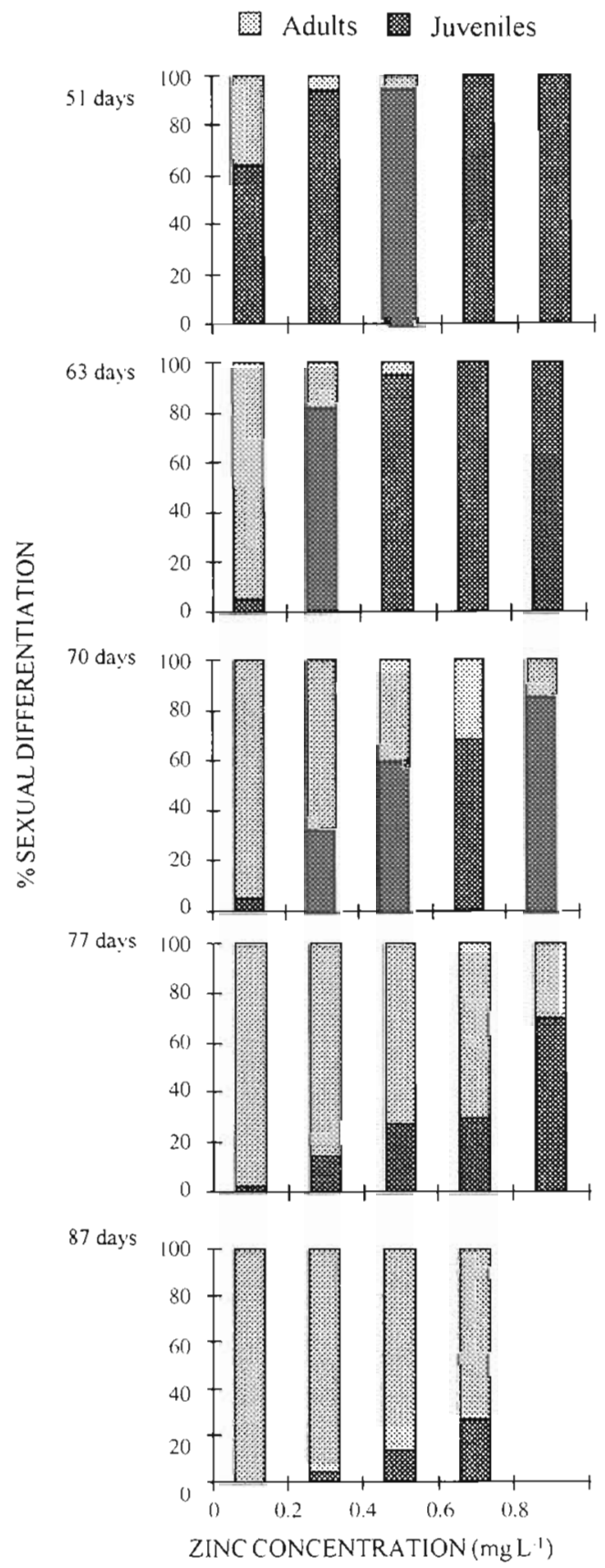

Fig. 3. Corophium volutator. Temporal variation in sexual differentiation of amphipods at different zinc concentrations

ies (Ahsanullah \& Arnott 1978, De Nicola et al. 1988, McCahon \& Pascoe 1988, Borowsky \& Aiteken-Ander 1989).

Growth rate is frequently used as a sublethal endpoint in ecotoxicological studies as it is usually reduced by environmental stressors (i.e. Maund et al. 1992, Moore \& Dillon 1993, Conradi \& Depledge 1998). Indeed, growth impairment in Corophium volutator 


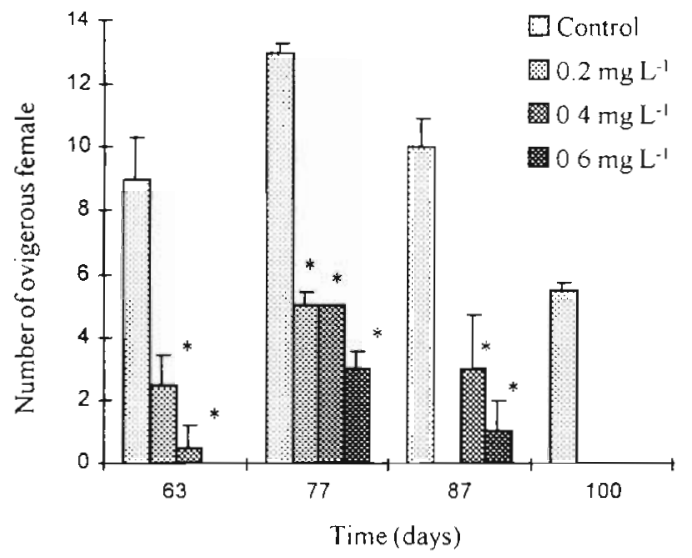

Fig. 4. Corophium volutator. Maturation (number of ovigerous females in the population) of amphipods at different zinc concentrations. Error bars show $+\mathrm{SE}_{\mathrm{i}} \cdot \mathrm{p}>0.001$

increases with increasing zinc concentration. This impairment in growth could be due to a reduction in the amount of metabolic energy available in the animal since zinc affects feeding (Weeks 1993), respiration and excretion ratios (Correa 1987), energy absorbed (Naylor et al. 1989) and moulting frequency (Drobne \& Strus 1996) in crustaceans.

Numerous studies have demonstrated that reduced growth in aquatic invertebrates, regardless of its cause, may be associated with concomitant reductions in reproductive output (Tolba \& Holdich 1981, Nisbet et al. 1989, Moore \& Dillon 1993, Ball \& Baker 1995). This is especially true in amphipods in general and in Corophium volutator in particular because of the linear relationship between fecundity and body size of females (Fish \& Mills 1979). However, the relationship between growth and reproduction exhibits a number of forms, each dependent on the manner in which energy is partitioned between somatic (non-reproductive) and gametic (reproductive) tissue development. If the allocations of energy to growth and to reproduction are affected similarly by an environmental stressor, a proportional (linear) relationship between growth and reproduction might be predicted. Conversely, if growth and reproduction respond with differential sensitivity, then the relationship between them disappears (Sibley et al. 1997).

Regardless of growth rate, animals have to obtain a minimal size before reproduction can occur (Rees \& Crawley 1989, Ankley et al. 1993). Therefore, the development of reproductive tissue is intimately related to somatic growth history in the sense that a critical somatic tissue mass must be accumulated before energy is allocated to the development of reproductive tissue (Rees \& Crawley 1989, Enserink et al. 1995). Environmental stressors that reduce somatic tis- sue development (i.e. growth) will also reduce, or prevent, gametic tissue development (e.g reproductive output). It has been demonstrated that Corophium volutator must attain $4 \mathrm{~mm}$ length prior to developing the ability to reproduce (Conradi \& Depledge 1998) Although zinc reduced the growth rate of this amphipod, most of the individuals reached this minimum size and, therefore, sexual differentiation of the most population was higher than $65 \%$ after $77 \mathrm{~d}$ of culturing. In which case, the impairment of reproduction in $C$. volutator would be expected to be much lower than it actually was if it were just a function of growth.

Some contaminants may act selectively on reproductive variables and, under these circumstances, growth would be a poor indicator of overall effects on reproductive success and population dynamics (Sibley et al. 1997). Indeed, the effect of zinc in Gammarus pulex was to change the energy from reproduction to the survivorship of females (Maltby \& Naylor 1990). These authors suggested that the broods were aborted due to the condition of the female rather than her offspring.

Reproduction is not without costs, both in terms of post-reproductive survival and future reproductive potential (Stearns 1989). Carrying a brood is likely to be energetically costly. If the energy status of a female is reduced (e.g. by stress) to the extent that by incubating a brood she jeopardises her own survival, then her overall fitness may be increased by sacrificing the broodlings and reproducing at a later date. As Corophium volutator is an iteroparus species, i.e. can have several broods in its lifetime (from 1 to 2 in Europe and North America up to 4 generations in Japan), ultimately it is not the number of surviving offspring in a single brood which is important but the total number of surviving offspring produced in the lifetime of a female, i.e. lifetime reproductive success. Thus, a possible explanation of the high degree of impairment in the reproduction of $C$. volutator provoked by zinc could be the increase in fitness of the animal associated with reallocating resources from reproduction to body maintenance and thereby increasing survival probability by postponing the production of broods. This is supported by the 'disappearance' of the ovigerous females (probably by absorption of the eggs or dead) when animals are grown at sublethal zinc concentrations (see Fig. 4) and by the great mortality of ovigerous females when mature individuals are exposed to zinc (see Fig. 5B).

Since ovigerous females were found when Corophium volutator populations were grown at different zinc concentrations, it is very unlikely that this metal alters the development of the reproductive organs. Nevertheless, some metabolic pathways involving moult cycle, which is closely associated with reproduction, could be altered by zinc (Drobne \& Strus 1996). In 
A

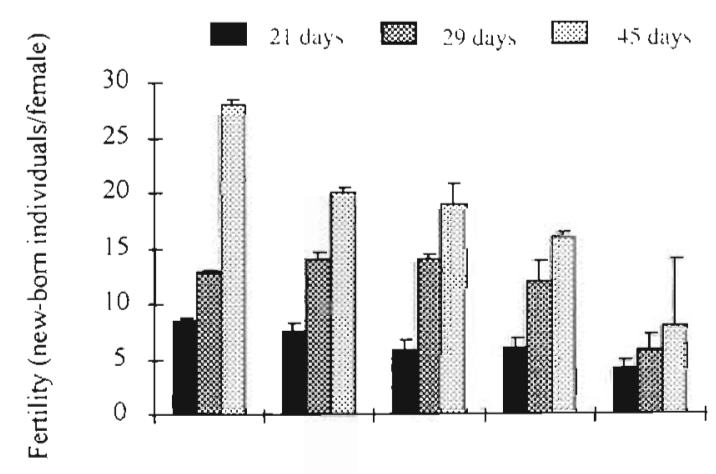

B

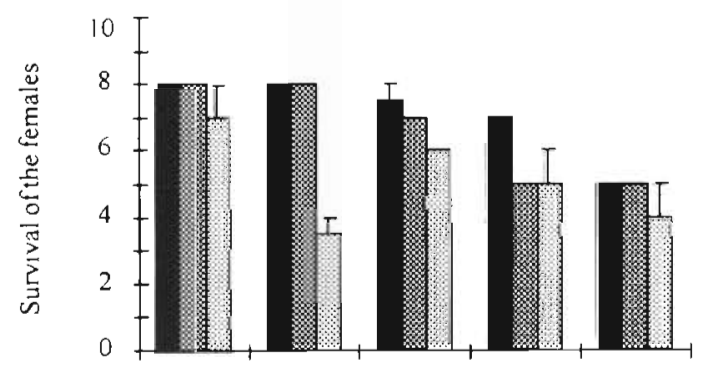

C

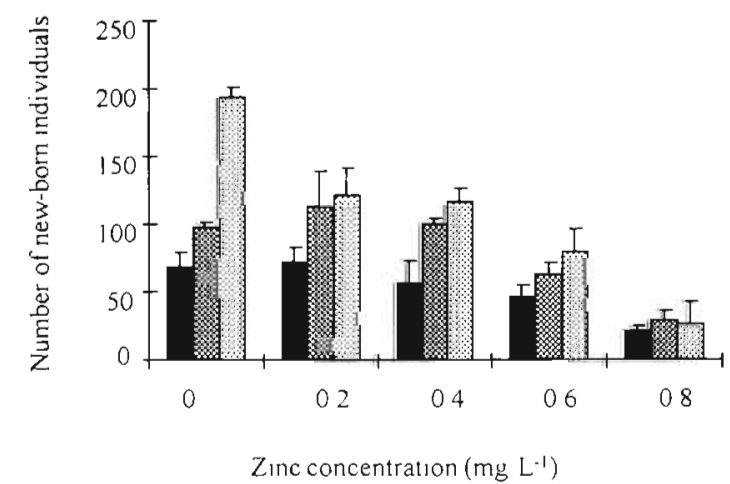

Fig. 5. Corophium volutator. Reproduction of mature amphipods exposed to different zinc concentrations: (A) fertility (no. of offspring per female), (B) survival of females, (C) number of individuals born. Error bars show $+\mathrm{SE}$

the case of both mature individuals and juveniles grown at various zinc concentrations, embryogenesis of C. volutator was affected. The damaging effects of trace metals on the embryogenesis of some amphipod species has been reported previously (Elmgren et al. 1983, Sundelin 1983). Zinc also directly reduced the survivorship of the new-born juveniles since, as pointed out above, this stage is one of the most sensitive.

In conclusion, short-term exposure of Corophium volutator to low concentrations of zinc (concentrations 70 times lower than the $\mathrm{LC}_{50}$ ) reduced fertility and survivorship of juveniles, thereby potentially leading to a severe population density decline. Long-term exposures would have more serious consequences since, although growth was only slightly impaired by zinc, reproductive output was dramatically reduced. These effects could lead to the local extinction of this species.

Acknowledgements. The project was supported by a grant from the Ministerio de Educación y Ciencia (Spain).

\section{LITERATURE CITED}

Ahsanullah M, Arnott GH (1978) Acute toxicity of copper, cadmium and zinc to larvae of Paragrapsus quadridentatus (H. Milne Edwards), and implications for water quality criteria. Aust J Mar Freshw Res 29:1-8

Ankley GT, Benoit DA, Hoke RA, Leonard EN, West CW, Phipps GL, Mattson VR, Anderson LA (1993) Development and evaluation of test methods for benthic invertebrates and sediments: Effects of flow rates and feeding regime on water quality and exposure conditions. Arch Environ Contam Toxicol 25:12-19

Ball SL, Baker RL (1995) The non-lethal effects of predators and the influence of food availability on the life history of adult Chironomus tentans (Diptera: Chironomidae). Freshwat Biol 34:1-12

Bat C, Hull S, Raffaelli D (1998) Uptake and accumulation of copper and zinc by the amphipod Corophium volutator (Pallas). J Exp Biol Ecol 223(2):167-184

Borowsky B, Aiteken-Ander AA (1989) Laboratory studies on the effects of toxic sediments on the life history of the amphipod crustacean Melina nitida. Am Soc Zool 29(4): $130 \mathrm{~A}$

Bryan GH, Langston WJ, Hummerstone LG, Burt GR (1985) A guide to the assessment of heavy metal-loading contamination in estuaries using biological indicators. J Mar Biol Assoc UK Occ Publ 4:1-92

Bryan V, Mclusky DS, Roddie K, Newbery DM (1984) Effect of temperature and salinity on the toxicity of chromium to three estuarine invertebrates (Corophium volutator, Macoma balthica, Nereis diversicolor). Mar Ecol Prog Ser 20:137-149

Bryan V, Newbery DM, McLusky DS, Campbell R (1985a) Effect of temperature and salinity on the toxicity of nickel and zinc to two estuarine invertebrates (Corophium volutator, Macoma balthica). Mar Ecol Prog Ser 24:139-153

Bryan V. Newbery DM, McLusky DS, Campbell R (1985b) Effect of temperature and salinity on the toxicity of arsenic to three estuarine invertebrates (Corophium volutator, Macoma balthica, Tubifex costatus). Mar Ecol Prog Ser 24: $129-137$

Calbet A, Alcaraz M (1997) Growth and survival rates of early developmental stages of Acartia grani (Copepoda: Calanoida) in relation to food concentration and fluctuations in food supply. Mar Ecol Prog Ser 147:181-186

Ciarelli S, Wies AP, Vonck MA, Van Straalen NM (1997) Reproducibility of spiked-sediment bioassays using the marine benthic amphipod, Corophium volutator. Mar Environ Res 43(4):329-342

Conradi M. Depledge MH (1998) Population responses of the marine amphipod Corophium volutator (Pallas, 1766) to copper. Aquat Toxicol 44(1-2):31-45

Correa M (1987) Physiological effects of metal toxicity on the tropical freshwater shrimp Macrobrachium carcinus (Linneo, 1758). Environ Pollut 45:149-155 
Daniels RE, Allan JD (1981) Life table evaluation of chronic exposure to pesticide. Can J Fish Aquat Sci 38:485-494

De Nicola M, Migliore L, Gambardella C, Marotta A (1988) Effect of chronic exposure to cadmium and copper on Asellus aquaticus (L.) (Crustacea, Isopoda). Hydrobiologia $157: 265-269$

Drobne D, Strus J (1996) Moult frequency of the isopod Porcellio scaber, as a measure of zinc-contaminated food Environ Toxicol Chem 15(2):126-130

Elmgren R, Hansson S, Larsson U, Sundelin B, Boehm PD (1983) The 'Tsesis' oil spill: acute and long-term impact on the benthos. Mar Biol 73:51-65

Enserink L, Haye M, Mass H (1995) Reproductive strategy of Daphnia magna: implications for chronic toxicity tests. Aquat Toxicol 25:111-124

Eriksson SP, Weeks JM (1994) Effects of copper and hypoxia on two populations of the benthic amphipod Corophium volutator (Pallas). Aquat Toxicol 29:73-81

Fish JD, Mills A (1979) The reproductive biology of Corophium volutator and $C$. arenarium (Crustacea: Amphipoda). J Mar Biol Assoc UK 69:11-15

Halcrow W, Mackay DW, Thornton [ (1973) The distribution of trace metals and fauna in the Firth of Clyde in relation to the disposal of sewage sludge. J Mar Biol Assoc UK 53: $721-739$

Kirk KL (1992) Effects of suspended clay on Daphnia body growth and fitness. Freshwat Biol 28:103-109

Krebs CJ (1978) Ecology. Harper and Row, New York

Lotufo GR, Fleeger JW (1997) Effects of sediment-associated phenanthrene on survival, development and reproduction. of two species of meiobenthic copepods. Mar Ecol Prog Ser 151:91-102

MAFF, Directorate of Fisheries Research (1992) Monitoring and surveillance of non-radioactive contaminants in the aquatic environment and activities regulating the disposal of wastes at sea, 1990. Aquat Environ Monit Rep 30. MAFF, Directorate of Fisheries Research, Lowestoft

Maltby L, Naylor C (1990) Preliminary observations on the ecological relevance of the Gammarus 'scope for growth' assay: effect of zinc on reproduction. Funct Ecol 4:393-397

Manley AR, Gruffydd LLD, Almada-Villela PC (1984) The effect of copper and zinc on the shell growth of Mytilus edulis measured by a laser diffraction technique. J Mar Assoc UK 64:417-427

Maund SJ, Taylor EJ, Pascoe D (1992) Population responses of the freshwater amphipod crustacean Gammarus pulex (L.) to copper. Freshwat Biol 28:29-36

McCahon CP, Pascoe D (1988) Use of Gammarus pulex (L.) in safety evaluation test-culture and selection of a sensitive

Editorial responsibility: Otto Kinne (Editor),

Oldendorf/Luhe, Germany life stage. Ecotox Environ Safety 15:245-2.52

Moriarty F (1983) Ecotoxicology: the study of pollutants in ecosystems. Academic Press, London

Moore DW, Dillon TM (1993) The relationship between growth and reproduction in the marine polychaete Nereis (Neanthes) arenaceodantata (Moore): implications for chronic sublethal bioassays. J Exp Mar Biol Ecol 173 $231-246$

Naylor C, Maltby L, Calow P (1989) Scope for growth in Gammarus pulex, a freshwater benthic detritivore. Hydrobiologia 188/189:517-523

Nisbet RM, Gurney WSC, Murdoch WW, McCauley E (1989) Structured population models: a tool for linking effects at individual and population level. Biol J Linn Soc 37:79-99

Norton MH, Eagle RA, Nunny RS, Rolfe MS, Hardiman PA, Hampson BL (1981) The field assessment of effects of dumping wastes at sea: 8 . Sewage sludge dumping in the outer Thames Estuary. Fish Res Tech Rep 62. MAFF, Directorate of Fisheries Research, Lowestoft

Redpath KJ (1985) Growth inhibition and recovery in mussels (Mytilus edulis) exposed to low copper concentrations. J Mar Assoc UK 65(2):421-431

Rees M, Crawley MJ (1989) Growth, reproduction, and population dynamics. Funct Erol 3:645-653

Roddie B, Kedwards T, Ashby-Crane R, Crane M (1994) The toxicity to Corophium volutator (Pallas) of beach sand contaminated by a spillage of crude oil. Chemosphere 29(4): $719-727$

Sibley PK, Benoit DA, Ankley GT (1997) The significance of growth in Chironomus tentans sediment toxicity tests: relationship to reproduction and demographic endpoints. Environ Toxicol Chem 16(2):336-345

Stearns C (1989) Trade-offs in life-history evolution. Funct Ecol 3:259-269

Sundelin B (1983) Effects of cadmium on Pontoporeia affinis (Crustacea: Amphipoda) in laboratory soft-bottom microcosms. Mar Biol 74:203-212

Tolba MR, Holdich DM (1981) The effect of water quality on the size and fecundity of Asellus aquaticus (Crustacea: Isopoda). Aquat Toxicol 1:101-112

Truhaut R (1977) Ecotoxicology: objetives, principles and perspectives. Ecotox Environ Safety 1:151-173

Van den Hurk P, Chapman PM, Roddie B, Swartz RC (1992) A comparison of North American and West European infaunal amphipod species in a toxicity test on North. Sea sediments. Mar Ecol Prog Ser 91:237-243

Weeks J (1993) Effects of dietary copper and zinc concentrations on feeding rates of two species of talitrid amphipods (Crustacea). Bull Environ Contam Toxicol 50:883-890

Submitted: March 31, 1998; Accepted: September 9, 1998 Proofs received from author(s): December 21, 1998 